\title{
About the biology of Steraspis fastuosa Gerstaecker in Atacora region, northern Benin (Coleoptera, Buprestidae)
}

\author{
by Jean-François VAYssières ${ }^{1}$, Charles L. BeLlamY ${ }^{2} \uparrow$, Georg Goergen ${ }^{3}$, \\ Appolinaire AdANDONON ${ }^{4}$, Antonio Sinzogan ${ }^{5} \&$ Gianfranco CuRLeTtI $^{6}$
}

${ }^{1}$ Centre International de Recherche Agronomique pour le Développement - UPR HortSys / International Institute of Tropical Agriculture, 08 BP 0932, Cotonou, Bénin <j.vayssieres@cgiar.org>

${ }^{2}$ Plant Pest Diagnostic Center, 3294 Meadowview Road, Sacramento, California (CA), 95832, U.S.A.

${ }^{3}$ International Institute of Tropical Agriculture, 08 BP 0932, Cotonou, Bénin

${ }^{4}$ National Higher School of Agricultural Sciences of Kétou, University of Abomey-Calavi, Bénin

${ }^{5}$ Faculty of Agricultural Sciences of Cotonou, University of Abomey-Calavi, Bénin

${ }^{6}$ Museo Civico di Storia Naturale, Via San Francesco di Sales 188, I - 10022 Carmagnola, Italie

Abstract. - Although numerous adults of the buprestid genus Steraspis Dejean, 1833, have been captured in West Africa, little is known about the biology of the known species, especially about their immature stages. The objective of the present field observations was to increase the knowledge on the biology of a common but localized species in Benin. In early 2012, a field survey was conducted to search for the immature stages of Steraspis species, especially S. fastuosa Gerstaecker, 1871. In May 2012, a nymph of S. fastuosa was found within the taproot of Acacia hockii De Wild (Fabaceae) and also an adult of the same species within the taproot of a nearby A. hockii. This welldeveloped adult was found at $7 \mathrm{~cm}$ below the soil surface and ready to emerge from the taproot. Prior to pupation, the mature larva had cut along the collar of the taproot, thus facilitating the emergence of the adult. This is the first report on the developmental biology of this species in West Africa.

Résumé. - À propos de la biologie de Steraspis fastuosa Gerstaecker dans l'Atacora (nord Bénin) (Coleoptera, Buprestidae). Bien que de nombreux adultes du genre Steraspis Dejean, 1833, aient été capturés en Afrique de l'Ouest, il existe peu d'information sur la biologie des espèces, spécialement concernant leurs stades préimaginaux. L'objectif du présent travail était d'améliorer la connaissance de la biologie d'une espèce commune, mais localisée, au Bénin. Début 2012, un travail de terrain a été conduit pour rechercher la larve de S. fastuosa Gerstaecker, 1871. Ainsi, en mai 2012, nous avons pu trouver une nymphe de $S$. fastuosa dans la racine principale d'un Acacia hockii De Wild (Fabaceae) ainsi qu'un adulte de S. fastuosa dans le pivot d'un autre A. hockii voisin. L'adulte était parfaitement formé avec les élytres durcis. Il était situé à $7 \mathrm{~cm}$ sous la surface du sol et prêt à quitter le pivot de l'arbre. La larve avait foré un trou ellipsoïde au niveau du collet de l'arbre puis l'avait garni de débris de bois compacté, ce qui facilite la sortie de l'imago du pivot. C'est la première observation concernant la biologie de cette espèce en Afrique de l'Ouest.

Keywords. - Chrysochroinae, Steraspis, biology, ecology, host-plant, Acacia hockii, Benin.

The family Buprestidae is one of the eight largest families of Coleoptera. Buprestidae comprises approximately 15,000 species within about 450 genera (Bellamy, 2008). To date, the genus Steraspis Dejean, 1833, contains 48 taxa (CURLETTI, 2009, 2010). Steraspis are large buprestid beetles belonging to the subfamily Chrysochroinae, subtribe Eucallopistina (BeLlamy, 2008), with nearly all species being restricted to habitats in subsaharan Africa, while two, Steraspis speciosa (Klug, 1829) and S. squamosa (Klug, 1829) are known from parts of North Africa and the Middle East.

In Benin, four species of Steraspis are known to occur: Steraspis (Steraspis) fastuosa Gerstaecker, 1871, S. (S.) modesta Kerremans, 1895, S. (Pissteras) infuscata Théry, 1908, and S. (P.) laetitia Curletti, 2011 (VAYssières \& Bellamy, 2012). The first three species were collected in the northern part of the country (departments of Atacora, Alibori, Borgou) and are common at a spatio-temporal scale but are rather localized species. The remaining one was only collected in central Benin (department of Collines) and is thus also restricted in distribution. 
Although many adults have been captured all over Africa, little is known about the biology of any of the known Steraspis species (CURLETTI, 2009). Few data on their host plants are yet available. For instance, $S$. (S.) speciosa was recorded from Acacia raddiana Savi in desert areas of southern Morocco (MATEU, 1975). S. (S.) squamosa was recorded from Tamarix gallica L. in Israel (HALPERIN, 1976) and from Tamarix spp. in Egypt (HAGgAG et al., 1996). Preliminary studies on Steraspis were launched a couple of years ago in Benin. Field investigations in this country lead to the first detection of an adult of $S$. infuscata within the taproot of a Combretum collinum Fresen. (Combretaceae) in May 2011 (VAYssières \& Bellamy, 2012). This well-developed adult was found $7 \mathrm{~cm}$ below the soil surface and ready to emerge. Prior to pupation, the mature larva had cut along the collar of the taproot, thus facilitating the emergence of the adult.

Further to this discovery, efforts were deployed in 2012 to find out about biological traits of the pre-imaginal stages of Steraspis fastuosa whose adults were recovered in Benin from Acacia hockii De Wild. (Fabaceae). In the present work, we tried to solve the question on the whereabouts of the larvae of $S$. fastuosa.

\section{MATERIAL AND METHODS}

Collection and synthesis of climatic data. - We used climatic data from Pendjari Park including daily temperature, relative humidity $(\mathrm{RH})$ and rainfall (data provided by the University of Abomey Calavi). Data were taken at a $1 \mathrm{~km}$ resolution interpolated climate surface, allowing thus an extrapolation for the climate of the Tanguieta-Pendjari and surrounding region.

Search for immature stages in the soil. - Previous observations indicated that adults of Steraspis fastuosa occur from beginning of August to beginning of November (VAYsSIÈrES \& BELLAMY, 2012). We therefore searched for immature stages of $S$. fastuosa during the month of May by the examination of all plant parts of Acacia hockii: branches, trunk, collar of the trunk, roots and taproot.

During the year 2012, two full days (12.V.2012 and 25.V.2012) were spent in the surroundings of Tanguieta, investigating species of $A$. hockii on which $S$. fastuosa could eventually be found. During these two days, we examined branches and trunks to ascertain that larvae were not living in the upper part of the tree. As already predicted, larvae were finally found to develop in the lower part of the tree which resulted in the excavation of the soil at the base when

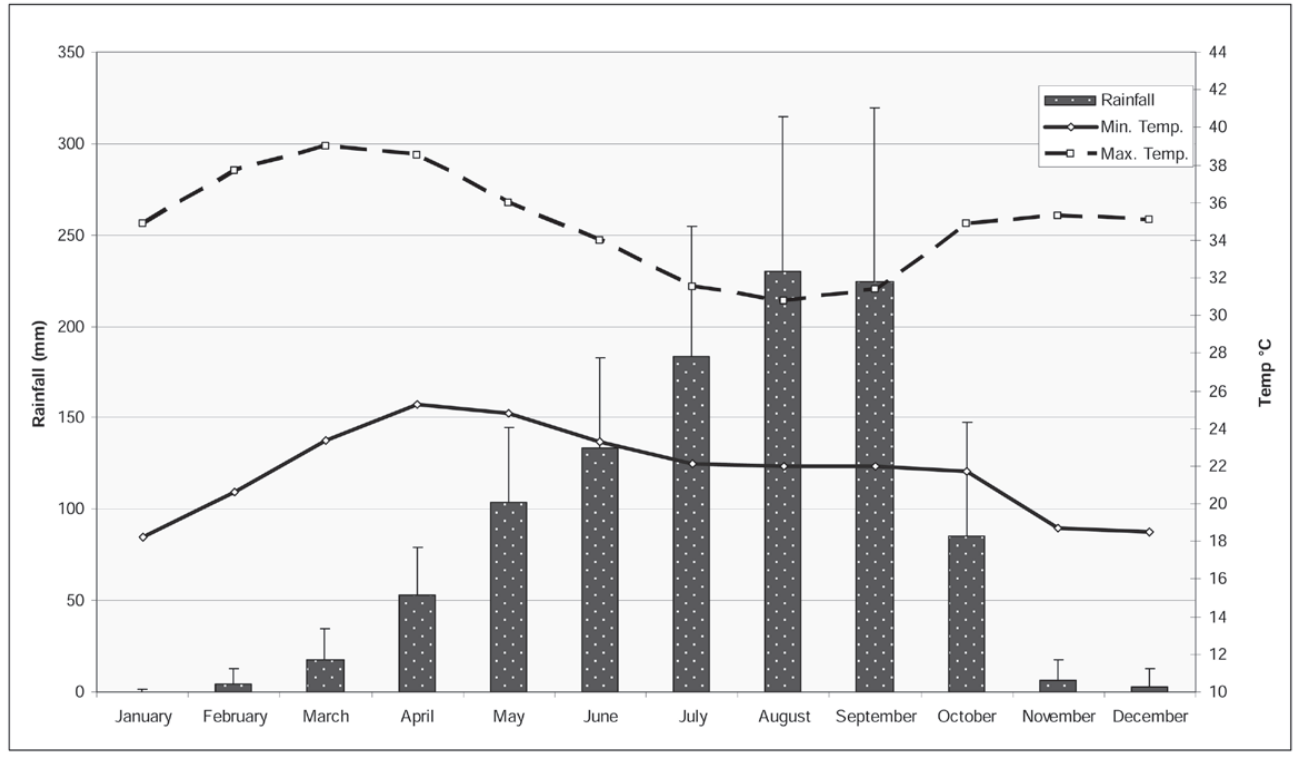

Fig. 1. - Climadiagram of Tanguieta-Pendjari region based on thirty years averages. 
inspecting every tree of that species. Because of the extreme hardness of soils in the area, the number of excavations per day remained relatively low. Consequently, only 25 Acacia hockii were prospected on the $12 . \mathrm{V}$ and 28 on the $25 . \mathrm{V}$.

\section{RESULTS}

Collection and synthesis of climatic data. - Fig. 1 shows long term averages (about 30 years) of monthly rainfall and temperature ranges for the Tanguieta-Pendjari region. The unimodal curve of rainfall clearly peaks during the month of August.

Field observations on adults and their host feeding behaviour. - Around Tanguieta and along the road to Batia, we regularly noted adults of Steraspis fastuosa on Acacia hockii between August and early November of 2011. These adults were observed to feed and rest on A. hockii trees (fig. 2). They usually attack very young stems (flush) of $A$. hockii during the morning (from $8 \mathrm{AM}$ to $10 \mathrm{AM}$ ) in August and September, an observation we already made during previous years. Toward the end of the morning (from $10 \mathrm{AM}$ to $12 \mathrm{AM}$ ), however, they usually circle around A. hockii, often around the top of the trees with a characteristic wheeling flight. They tend to rest on the trees (from 1 PM to 4 PM) when the sun is more intensively shining.

Search for immature stages in the soil. - We got two positive results the 25 .V. On tree $n^{\circ} 1$, dry branches indicated strong weakness symptoms of $A$. hockii (fig. 3) though most of the remaining tree parts were still surviving. When the soil at the bottom of the tree was cleared away, a long gallery growing up towards the base along a lateral root became visible (fig. 4). It was presumed to be the first step of the infestation. After complete extraction of the tree (fig. 5), we sawed the trunk in order to make sure that no gallery was coming down from the upper part of the tree. Following the splitting of the taproot we quickly recognized a gallery (fig. 6) in the middle of the taproot, containing a few small pieces of wood. As displayed in fig. 6, the emergence hole was sealed with compact little pieces of wood agglomerated just beneath the soil surface $(1 \mathrm{~cm}$ below). So, the larva had made an opening in the upper part of the taproot, allowing the emergence of the adult. During the root examination a perfect imago of Steraspis was attempting to come out (fig. 7) from the base but reversed its way slowly following disturbance (fig. 8). However, after feeling safe, the adult of $S$. fastuosa left the gallery and stayed on the taproot (fig. 9). The vertical gallery had a length of $35 \mathrm{~cm}$ within the taproot and ended in a pupal chamber of about $5 \mathrm{~cm}$ just below the emergence hole. Since this adult was fully developed it is likely that he was only waiting an emergence cue to finally leave its host-plant.

On tree $\mathrm{n}^{\circ} 2$, we also observed similar weakness symptoms as the previous tree, i.e. dry branches (fig. 10). While pulling the little trunk, it suddenly broke and split up from its base (fig. 11). Among little wood debris the head of a nymph could clearly be distinguished inside the pupal chamber (fig. 11) just beneath the soil surface. The nymph was extracted (fig. 12) and within a few weeks reared to a perfect imago of $S$. fastuosa. A more humid soil for the tree $\mathrm{n}^{\circ} 2$ probably delayed full maturation of the beetle.

\section{DISCUSSION}

To date, only few data are available about the specificity of tropical Buprestidae infesting forest trees and more especially in West Africa. Those presently accessible concern the specificity of xylophagous beetles in West Africa by WAGNER et al. (1991), and xylophagous insects of Saharo-sahelian Acacia species published by MATEU (1975). The biology of Steraspis speciosa is described therein and indicates that eggs are deposited on the top of a branch of Acacia raddiana. Following emergence, the larvae work their way down inside the branch, causing visible damage and ending with an emergence hole directly on the branch. S. speciosa is therefore categorized as a primary xylophagous beetle which can inflict serious damage to Acacia trees in Saharo-sahelian areas (MATEU, 1975). Our observations show that $S$. fastuosa is too a primary species infesting another Acacia species in Sudanian areas of West Africa. Considering that a larval gallery was 

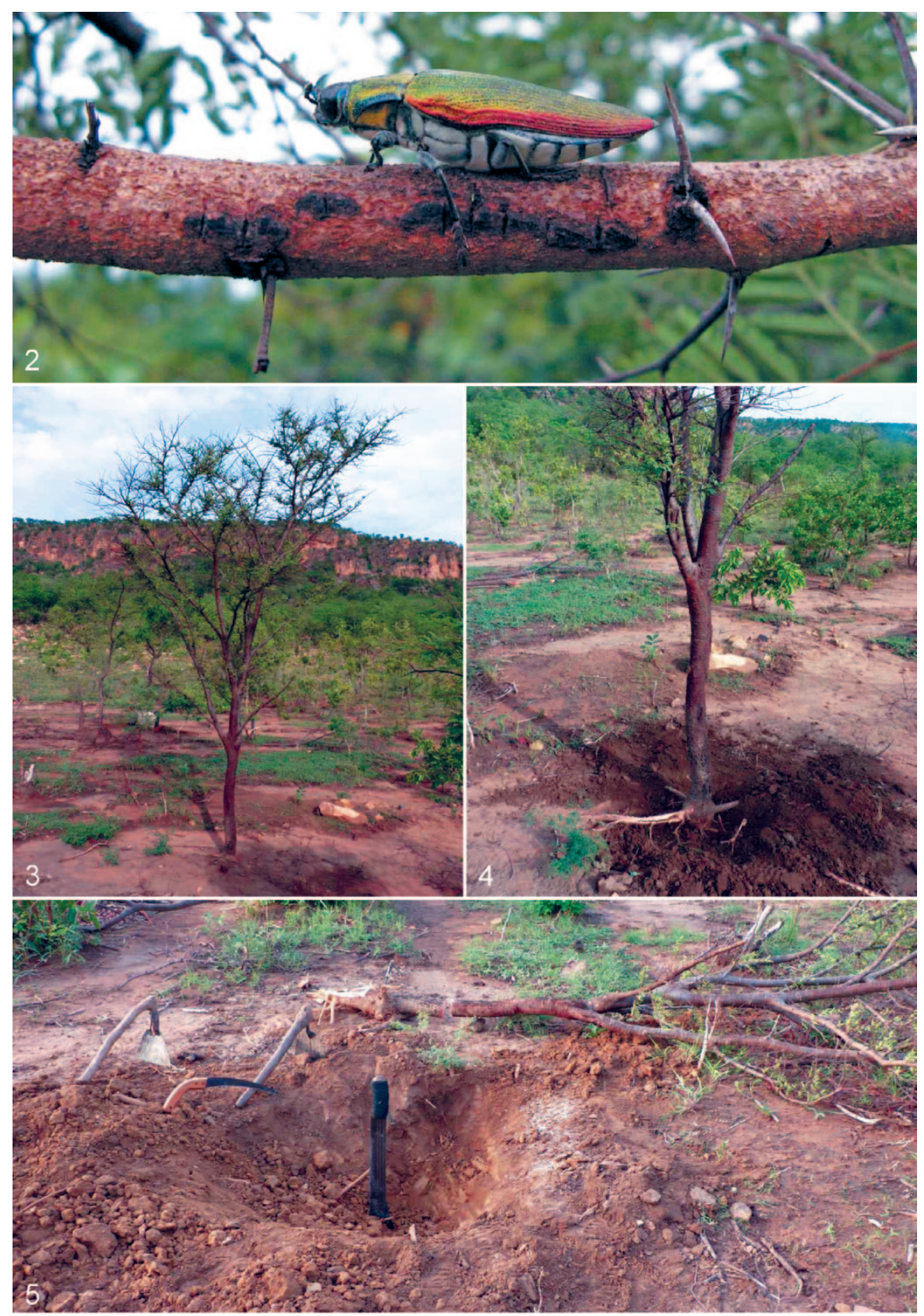

Fig. 2-5. -2, Steraspis fastuosa Gerstaecker on Acacia hockii De Wild. at bottom of the cliff of Tanguieta (NW Benin). -3-5, Acacia hockii De Wild., tree $n^{\circ} 1: 3$, damages with dry branches (weakness of the tree); 4 , infestation by larva of $S$. fastuosa on lateral root; 5 , excavation of $40 \mathrm{~cm}$ depth at bottom. 

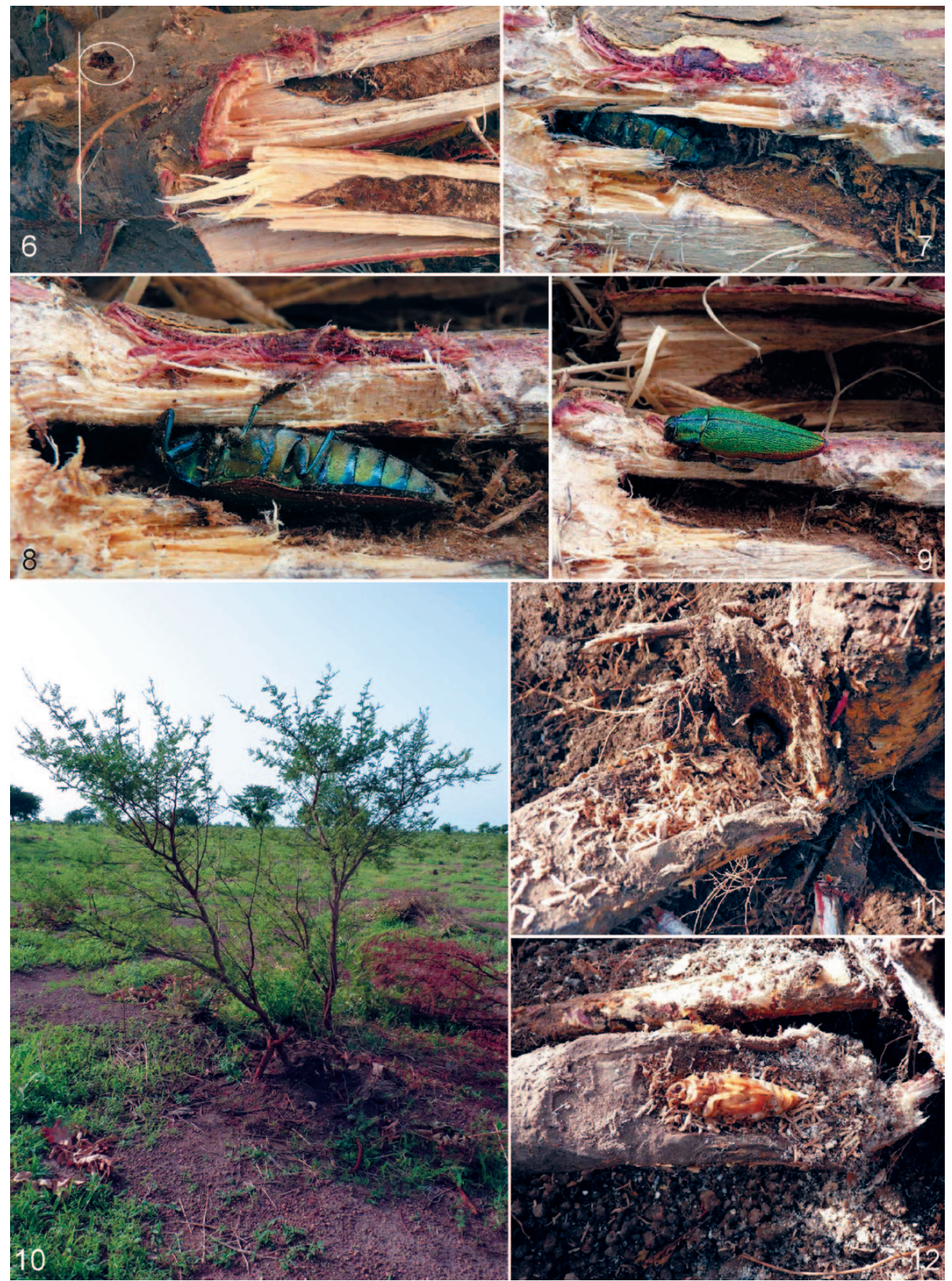

Fig. 6-12. - 6-9, Acacia hockii De Wild., tree ${ }^{\circ} 1 ; 1$, infestation inside the taproot and emergence hole (white ellipsoid) of $S$. fastuosa Gerstaecker just under ground level (white trait); 7, adult of $S$. fastuosa inside the gallery in the taproot and coming out; 8, adult of $S$. fastuosa reversing inside the gallery in the taproot; 9, adult of $S$. fastuosa outside the gallery staying on the taproot. - 10-12, Acacia hockii De Wild., tree ${ }^{\circ} 2 ; 10$, damages with dry branches (weakness of the tree); 11, nymph of S. fastuosa inside the taproot (in habitat) among tree-debris; 12, nymph of S. fastuosa (ex habitat) extracted from the gallery among many tree-debris. 
not found in the cut trunk (tree $\mathrm{n}^{\circ} 1$ ) but in the root (fig. 3), it is suggested that the egg of S. fastuosa is deposited on the lateral root of A. hockii. A second observation on another Acacia hockii (tree $\mathrm{n}^{\circ}$ ) also shows that there was no larval gallery in the trunk. All pre-imaginal stages of S. fastuosa associated with $A$. hockii seem to be hypogeous in Atacora region.

So far in Africa, the few data recorded from Steraspis species show that $\left.1^{\circ}\right) S$. speciosa lives within branches and/or trunks of Acacia raddiana (MATEU, 1975), $2^{\circ}$ ) $S$. squamosa lives within branches-trunk of Tamarix spp. (HaGGaG et al., 1996), $3^{\circ}$ ) S. infuscata lives within the taproot of Combretum collinum (VAYssières \& BELLAMY, 2012), and $4^{\circ}$ ) $S$. fastuosa lives within the taproot of Acacia hockii. Our personal observations made in a geographical area stretching from Morocco to Benin allow us to stress the fact that buprestid females did not lay eggs on arbitrary chosen trees but on such ones showing special symptoms not often visible at first glance. It is often the physiological stage of the tree, stressed by fire, cattle or an abiotic factor, which triggers the wilting and thus its attractiveness for the beetles (HANKs, 1999).

More generally, human pressure in the African continent has resulted in a deforestation rate three times higher than in other continents, causing irreversible loss of biodiversity. For instance, Benin has lost more than $35 \%$ of its forest surface from 1990 to 2008 . The increasing destruction of forest ecosystems is a serious threat hampering advances in the knowledge of the rich biodiversity found in the dry forest areas of Benin. The food-web structure of xylophagous beetles with all their associated species is as unique as important for the resilience of biodiversity in forest ecosystems (Grove \& STORK, 1999). Furthermore, climate change (GIEC, 2001) adds to this threat which may well compromise perspectives for a sustainable evolution of all these insect communities.

AcKnowledgments. - We would like to thank Mr. Lazard Adoho for his help in the field.

To our great sadness, Dr Charles "Chuck" Bellamy passed away on Monday August $19^{\text {th }} 2013$. The authors are deeply indebted to Chuck for his guidance, exchange of vast knowledge, support, and sharing of specimens.

\section{REFERENCES}

Bellamy C. L., 2008. - A World Catalogue and Bibliography of the Jewel Beetles (Coleoptera: Buprestoidea). Volume 1: Introduction; Fossil Taxa; Schizopodidae; Buprestidae: Julodinae - Chrysochroinae: Poecilonotini. Pensoft Series Faunistica, n ${ }^{\circ 6}$. Sofia-Moscow: Pensoft Publishers, 625 p.

Curletti G., 2009. - Sul genere Steraspis Dejean, 1833 (Coleoptera, Buprestidae). Bollettino del Museo Regionale di Scienze naturali di Torino, 26 (1-2): 83-153.

- 2010. - Quattro nuove specie del genere Steraspis Dejean, 1833 (Coleoptera, Buprestidae). Bollettino del Museo regionale di Scienze naturali di Torino, 28 (1): 85-107.

GIEC, 2001. - Changements climatiques 2001 : rapport de synthèse. Geneva: Groupe d'experts intergouvernemental sur l'évolution du climat, $124 \mathrm{p}$.

Grove S. J. \& Stork N. E., 1999. - The conservation of saproxylic insects in tropical forests: a research agenda. Journal of Insect Conservation, 3: 67-74.

Haggag S. M., Girgis G. N., Batt A. M. \& Okil A. M., 1996. - Biological studies on the tamarisk Jewel borer, Steraspis squamosa Klug (Coleoptera, Buprestidae) in Egypt. Egyptian Journal of Agricultural Research, 74: 1013-1020.

HALPERIN J., 1976. - The biology of the tamarisk buprestid - Steraspis squamosa-. Gan Vanof, 3: 232-240.

HANKs L. M., 1999. - Influence of the larval host plant on reproductive strategies of cerambycid beetles. Annual Review of Entomology, 44: 483-505.

Mateu J., 1975. - Les insectes xylophages des Acacia dans les régions sahariennes. Porto: Imprensa Portuguesa, $705 \mathrm{p}$.

VAYsSIÈres J.-F. \& BeLLAmy C. L., 2012. - About the biology of Steraspis infuscata Théry and data of additional species of Steraspis collected in Benin (Coleoptera, Buprestidae). Bulletin de la Société entomologique de France, 117 (2): 179-185.

Wagner M. R., Atuahene S. K. N. \& Cobbinah J. R., 1991. - Forest entomology in West tropical Africa: Forest Insects of Ghana. Dordrecht: Kluwer Publishers, 210 p. 